\title{
Career Development And Organizational Climate On Employee Commitment (Case Study On Bank Syariah Indonesia)
}

\author{
K. F. Afgani, D. Pringgabayu, and R. Purbayati
}

\begin{abstract}
Human Resources (HR) is a very important part in PT Bank Syariah Indonesia, so that it is expected that there is an ideal and sufficient working period to optimize employee careers and increase employee commitment to the company, considering the products produced by the company are products used to facilitate the state apparatus work system and service to the wider community.

This study aims to determine the effect of variable Career Development and Organizational Climate on the commitment of Employees in PT Bank Syariah Indonesia. The method used in this study is a research mix method, which is a step of research by combining two forms of approach in research that is quantitative and qualitative. The population in this study were all employees in the Bank Syariah Indonesia as many as 53 employees

The results showed that the career development variable (X1) and also the Organizational Climate (X2) had a positive and significant effect on the variable Employee Commitment $(Y)$. The conclusion of the research shows that to increase the commitment of employees in PT Bank Syariah Indonesia, the company needs to improve the existing career development system and maintain the organizational climate so that it remains conducive for all employees.
\end{abstract}

Index Terms - Career development, organizational climate, employee commitment

\section{INTRODUCTION}

Bank bjb Syariah always prioritize good relationships with clients, as a form of corporate commitment in serving clients and providing the best and professional services. In order to empower human resources, especially in the environment where the research object is not separated from the construction that aims to achieve the best organizational objectives in the company's operations. One of the factors that determine the success of the organization to meet the needs of the client is the employees, then every organization needs human resources that are competent as the competitiveness of the company to achieve the success of employees in working.

Conditions that occur in the object of research describe the company prioritizes customer satisfaction so that human resources are less attention, there are several problems that

Published on July 4, 2020.

K. F. Afgani, School of Business and Management, Institut Teknologi Bandung, Indonesia.

(corresponding e-mail: kurnia.fajar@ sbm-itb.ac.id

D. Pringgabayu, School of Business and Management, Institut Teknologi Bandung, Indonesia.

R. Purbayati, School of Business and Management, Institut Teknologi Bandung, Indonesia. can be identified, based on the results of information in the field, there are some facts that show a portrait of employee commitment to the organization in the company, career development applied by Bank Syariah Indonesia whether it can have an impact on capacity building, the way the company always requires employees to work independently by making one of the job descriptions to employees, namely, to deliver results and present their work directly to the kilen until the job is complete.

Employees who are always required to work independently of these things are good for individual ability but the description of the condition in the field is not a few employees complain about it, such as the task of supervisors done by the staff, placements that have not been in accordance with the skills and there are no candidates in the replacement of the supervisor at the time holder of the post [2], [9].

Portraits of career development in the company will generally conduct training or training to employees on a period basis as needed to support the company [7]. While in the company where the object of this research employees are asked to do work with the skills that have without training first, whether the way to facilitate and add experience to employees to deal with clients [5]. Human Resources that will be joined in the hopes of having experience in accordance with the position of the Dilamar, of course it is often done by some companies to obtain a competent candidate but in that way there are not very few employees who resign before passing the deadline of employment agreement or probation in Bank Syariah Indonesia.

The high number of employees who resign with a variety of reasons is certainly very in the impact of the company, one of which is when the employee resigned before completing the product, there will be complaints from clients that lead to reduced corporate opportunities, then there is vacancy in the position when the coordinator of the Resign division or in the pull into the leadership of the subsidiary, Low training, training, clarity of status and career led employees are reluctant to continue their careers in Bank Syariah Indonesia, no desire arising from employees to survive as a member of the company, portrait support given by the company to employees in terms of career to describe the condition.

Corporate management support in career planning certainly helps to answer the certainty of the status of the employee both from the position, assignment and other responsibilities given by the company [6]. Based on the observation and discussion above, seen a career development portrait of Bank Syariah Indonesia Company 
on the commitments that the employees have, making the authors want to dig further to know the conditions that actually happened to the service company.

Based on the field observation, the pot was obtained a fairly interesting phenomenon, which is currently facing problems with the high turnover rate of employees, especially those experienced by employees who are still young (less than 30 years old). Bank Syariah Indonesia Management provides employee data for research, and has been pre-survey using questionnaire instrument with the statement. The following are attached portraits of presurveys that have been in response to 27 (twenty-seven) employees:

TABLE 1. PRE-SURVEY RESULT ON CAREER DEVELOPMENT

\begin{tabular}{|c|l|c|c|}
\hline No. & \multicolumn{1}{|c|}{ Career Development Statements } & High & Low \\
\hline 1 & Career planning for every employee who has competency & 7 & 20 \\
\hline 2 & $\begin{array}{l}\text { A company that has given development career opportunity for } \\
\text { every employee }\end{array}$ & 8 & 19 \\
\hline 3 & $\begin{array}{l}\text { Employee training programs are carried out annually by the } \\
\text { company to increase competency }\end{array}$ & 4 & 23 \\
\hline 4 & $\begin{array}{l}\text { The company provides an opportunity to enhance the ability of all } \\
\text { employees }\end{array}$ & 10 & 17 \\
\hline 5 & $\begin{array}{l}\text { The company places the position in accordance with the expertise } \\
\text { possessed by employees }\end{array}$ & 11 & 16 \\
\hline 6 & Promotion is given to the excellent employees & 7 & 20 \\
\hline 7 & Company support in employee career development & 6 & 21 \\
\hline 8 & Career development information has been submitted and planned & 5 & 22 \\
\hline & Number of questions from the respondent's response & 58 & 158 \\
\hline
\end{tabular}

The table above shows a portrait of a respondent's response from the given statement about career development in the company, a portrait of a respondent made by the employer about career development of employees, both in long-term planning, promotion to employees who are wellperforming and support from the company regarding employee career. Overall, it can be seen that the career development portrait in BSI is still considered lacking, and it is supported by the career path model that can be said is still very simple, as illustrated in the chart below:

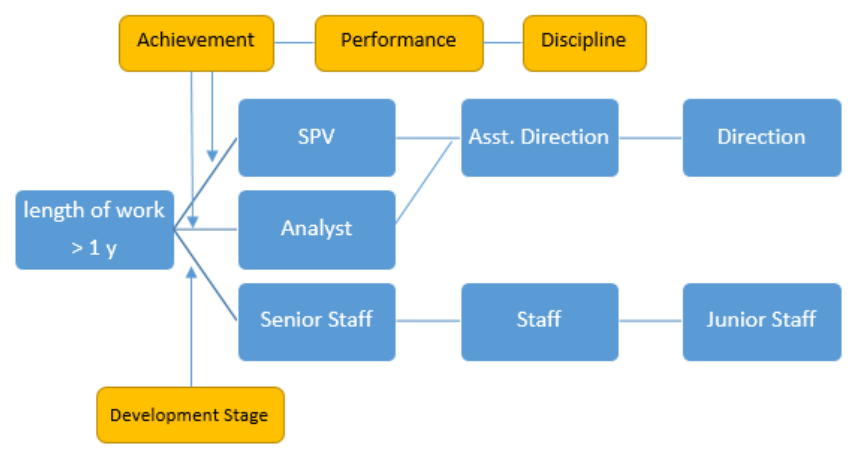

Fig. 1. Current Career Path

In Figure 1, it is hoped that employees are expected to have a career up to the board of directors when they have achievements that include good votes. But employees can only achieve the highest career as senior staff if the employee is still considered in the development stage by the management, so that his highest career can only reach the senior staff. Pre-observation results also show that at BSI, the career path is based solely on Pretation, performance, discipline and experience only, not based on the competency level of each employee who is then adjusted to the possibility to be promoted.

In the opinion of some employees interviewed by the authors at the time of pre-survey, delivered that employees have not felt any transparency in terms of career development, especially if viewed from the criteria or reasons used by the management of the top, when employees are promoted to a certain position, while on the other party is not a few employees who have worked long enough in PT BSI, but in fact still remain in the same position, without any offer or development of career yang clear and.

If viewed from the problem IN PT BSI presented in Figure 1 above, then one of the variables related to it means still low employee commitment. As for the commitments, the results of pre-survey research appear to be an overview of most employees having a working period of under 2 years or $85 \%$ (eighty five percent) of total employees, This is a description of the condition with the working period in the table whether the employee is fully adapted, or contributing to the company and human resource description owned by the company as a competent asset to fill in important positions.

Of course, it is hoped that the ideal and adequate working period to optimize employee career and increase employee commitment to the company, considering that products produced by the company are products used to facilitate the work system of State apparatus and service to the wider community.

In addition to career development, low employee commitment to the company is also an indication of problems in the organizational climate. Where according to Mathis \& Jackson (2011) The climate of the organization directly or indirectly will affect the desire of employees to think keep working in the same company or think of moving the workplace.

Referring to the explanation above, considering that the company that has stood almost ten years but seems to picture most employees have a working period under 2 years or $85 \%$ of the total employee, this is a description of the condition with the working period whether the employee is fully adaptable or contribute to the company and a picture of the company's resources to have competent employees to fill important positions. Of course, it is hoped that there is an ideal and adequate working period to optimize employee career and increase employee commitment to the company, considering that the product produced by the company is a product that is used for government benefit.

Based on the background of the above, the author is interested in conducting research on "Career Development and Climate organization to employee commitment (case study at PT. Bank Syariah Indonesia)" The result will be poured out in the paper.

\section{MethodOLOGY}

This research is mixed methods research, which is a research step by combining two forms of approach in the research that is quantitative and qualitative. Mixed research is a method that combines qualitative research with quantitative research [1]. Meanwhile, according to Sugiyono [8] Mix Methods is a method of research by combining two methods of research at once in a research activity, so that the data will be obtained more comprehensive, valid, reliable 
and objective.

The mix methods approach is required to answer the problem issues that have been addressed in the first chapter, the formulation of such problems can be answered through both quantitative and qualitative approaches. This is done to find problems in the field that will provide a new understanding for each organization to solve the problem.

This research is conducted with the aim of knowing the career development and climate of the organization towards employee commitment in the company and what kind of career development model can be applied in order to increase employee commitment.

Population In this research is all employees at Bank Syariah Indonesia Bandung (BSI), which is as many as 53 employees. In this study all employees of BSI Bandung, the population to be researched there are several different characteristics that are expected to reflect the problems that will be researched

In determining the samples used in this study, the authors use a technique based on non probability sampling technique i.e. Total Sampling, then the researcher will use all of the total employees in Bandung that will be used as samples to be researched, so the number of the population studied is as much as 53 Employees.

Once the necessary data is obtained then the processing of data by arranging the data and adjusted to the variables to be researched, to know the description of each variable, will be performed a descriptive analysis to test the data, conducted a verification in a verified to calculate and see if there is influence of career development and climate organization to increase employee commitment.

\section{RESEARCH RESULT}

After conducting statistical data for descriptive and verification analysis, as well as reconfirming to respondents through in-depth interviews, overall the authors get information that both career development, organizational climate and employee commitment at PT BSI are still in the less good category.

VAriabel Career Development (X1) has a positive and significant influence on the variable employee commitment (Y). The magnitude of the influence of career development variables on employee commitments can be seen through coefficient of determination (KD) analysis which is assessed from the amount of Rsquare (R2) value with the following calculations:

$$
\mathrm{KD}=\mathrm{R} 2 \times 100 \%=0.400 \times 100 \%=40 \%
$$

It can be concluded that the career development variable has an impact of $40 \%$ in shaping the employee's commitment, while the other $60 \%$ is formed by other variables not raised in this study.

"Career development of employees plays an important role in enriching the human capital component of a company. It is being strategically used to leverage organizational talent, and to attract and retain a competent workforce (Ulrich, 2014). Therefore, a career development program is assumed as a belief by each employee to achieve a desired career in an organization, and to realize career planning objectives tailored to the organizational conditions. Some indicators to measure career development include career needs, corporate support in the form of morals, company support in the form of material, training, fair treatment in a career, career information, promotion, transfer and employee development. If career development has been carried out by the company, the company is able to have competent and qualified employees to achieve common goals, thereby affecting employee commitment.

Organizational commitment is a psychological bond of employees to organizations characterized by the strong trust and acceptance of organizational objectives and values, willingness to strive for organizational interests, and a strong desire to maintain a position as a member of the organization. Organizational commitment is defined to give the identity to the people by involving and sharing them in the specific organization (Gunluetal et al., 2010).

Then the organizational climate variable (X2) has a positive and significant influence on the variable employee commitment (Y). The magnitude of the influence of the organizational climate variable on employee commitment can be seen through a coefficient of determination (KD) analysis which is assessed from the amount of Rsquare (R2) value with the following calculations:

$$
\mathrm{KD}=\mathrm{R} 2 \times 100 \%=0.417 \times 100 \%=41.7 \%
$$

So it can be concluded that the organizational climate variable has an impact of $41.7 \%$ in shaping the employee's commitment, while the other $58.3 \%$ is formed by other variables not raised in this study

According to Lussier [3] said that organizational climate is employee perceptions about the quality of the organization's internal environment that is relatively felt by members of the organization which will then affect their subsequent behavior. The internal environment of an organization which is perceived and felt by employees to have a relationship with what is planned by the organization, can routinely motivate employees or vice versa. Organizational climate felt by individuals positively (pleasant) will provide a good and effective work appearance that will affect the success of the organization. Organizational climate that occurs in every organization will affect organizational behavior as measured through the perception of each member of the organization.

According to Robbins (2013) Employee commitment to the organization is up to the level at which an officer sided with a particular organization and its objectives, and intends to maintain membership in a particular organization. In achieving a good performance every employee in an organization must have a behaviour involving a sense of loyalty to the organization

Some of the respondents who interviewed the authors stated that basically career development in the company is not optimal, in the sense that the employee considers to have a higher career in the technological landscape takes a short time, and not a few employees who complained that he did not know what requirements or competencies needed to be able to rise to a higher career position.

One example is that there is still no proposal from the company to employees to participate in certain training or 
workshops that are beneficial to develop their competence, so that more often employees develop their knowledge because of the knowledge transfer from employees who are more senior or minimal by studying the sciences in relation to the field of work.

In general, according to employees, that the employee career development has the benefit to the interests of the Organization and the personal interests of the employees themselves, the development of the company's business for the future of employees can improve the professionalism of employees and encourage the achievement of program objectives and organizational objectives effectively and efficiently. As for the employees themselves, can add knowledge, skills and improvement of ability, so that in working has a burden that is felt mild with a clear and more open career opportunities.

Based on some input from the respondents, the author compiled a new career development model that is expected to be implemented in PT BSI so as to overcome the career development problems that have been happening. The Model in question is as follows:

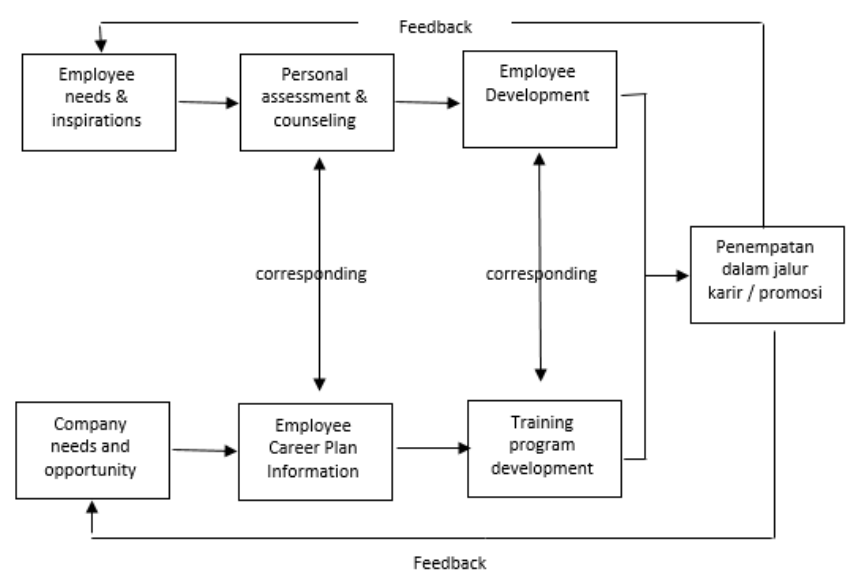

Fig. 2. Career Path Development Model

In the figure above, the author tries to compile a new career development model, which explains that if the employee wants to be placed in a particular career path or on a promotion, then the company must first know what the employee's needs and inspiration are in working, how to do an assessment pesonal also conducts in-depth counseling so that the direction of employee development is most appropriate according to the capabilities of the employee. While on the other hand the company must also pay attention to the company's needs for certain positions, and from these needs then matched with the information the company has from the results of counseling and personal assessment of employees. After that, the results of the assessment will appear in accordance with the needs of the company, so that if an employee who matches the needs of the company but is deemed not to have sufficient competence, the employee will be placed in an employee development program through adequate training and education. If all the steps are carried out properly, then the employee concerned will get the opportunity to be promoted according to their respective competencies, and in accordance with company needs.

After discussing career development, the next variable is regarding organizational climate. One form of organizational climate that is still often complained of by employees based on the results of interviews is the lack of opportunity to hold discussions in a direction when there is a problem in the work at hand. According to the employees, when there is a problem, it is directly discussed and the solution is discussed right away, so that it does not develop into a situation that causes the parties concerned to become disputed as often occurs at BSI.

Employees also convey openness from superiors to employees, especially those related to work results which later also relate to employee performance appraisal. Some of the employees interviewed still stated that sometimes the performance appraisal provided by their superiors seemed unfair, and superiors were more likely to give less feedback to employees or subordinates if problems were found. In fact, what employees really want is a conducive climate, especially from superiors to subordinates related to the openness and transparency of work results, the aim is to ensure that employees know what mistakes or deficiencies can be corrected for the future.

Employee commitment is also a dimension of employee behavior that can be used to assess employee attitudes towards the organization, by identifying and seeing someone's involvement that is relatively strong towards the company, then the employee will be willing to strive to achieve organizational goals, with support throughout the organizational environment conducive everything will be useless if there is no employee commitment in organizational development.

\section{CONCLUSION}

Based on the research results that have been shown in the previous chapter, the author took the following conclusions:

Based on the data processing results in a descriptive, then it can be known that overall response of respondents to the career development variables In PT BSI is still in the category of less good. Of the seven indicators used in this variable, it appears that the indicator that the highest average score is in the company's statement has good management for recruitment and selection of new employees, while the lowest average score on the company's statement has a good assessment of the development of employee capability.

For the organizational climate variable, based on descriptive data processing results can be known that overall the respondent's response to the perceived organizational climate variable in the company is still in the less good category. Of the twenty indicators used in this variable, it is apparent that the indicator that the highest average score exists in the company statement has a rule that is easily applied to all employees, while the lowest average score is in the opinion disagreements between employees can be easily resolved through a directional discussion

Then for the variable employee commitment, based on the results of the data processing in a descriptive, then it can be known that the overall response of respondents about the variable commitment of employees who felt at PT BSI still in the category of less good. Of the 10 indicators used in this variable, it is apparent that the indicators that get the highest average score are on the work statement in this company 
because I am so able to meet my life's needs, while the lowest average score is on the work statement in this company because today's tough to get the job

Simultaneous, the career development variables (X1) and the organizational climate (X2) have a significant influence on the employee's commitment (Y). While partially, career development variables have an impact of $40 \%$ in shaping employee commitments, while organizational climate variables have an influence of $41.7 \%$ in shaping employee commitments.

\section{REFERENCES}

[1] Creswell, J. W., \& Clark, V. L. P. (2017). Designing and conducting mixed methods research. Sage publications.

[2] Jyoti, J. (2013). Impact of organizational climate on job satisfaction, job commitment and intention to leave: An empirical model. Journal of business theory and practice, 1(1), 66-82.

[3] Lussier, R. N., \& Achua, C. F. (2015). Leadership: Theory, application, \& skill development. Nelson Education.

[4] Mathis, R. L., \& Jackson, J. H. (2011). Human resource management: Essential perspectives. Cengage Learning.

[5] Rahimic, Z. (2013). Influence of organizational climate on job satisfaction in Bosnia and Herzegovina companies. International Business Research, 6(3), 129.

[6] Riad, L., Labib, A., \& Nawar, Y. S. (2016). Assessing the impact of organisational climate on employees commitment. The Business \& Management Review, 7(5), 357.

[7] Sharf, R. S. (2016). Applying career development theory to counseling. Nelson Education.

[8] Sugiyono. (2011). Memahami penelitian kualitatif. Bandung: Alfabeta

[9] Vondracek, F. W., Lerner, R. M., \& Schulenberg, J. E. (2019). Career development: A life-span developmental approach. Routledge.

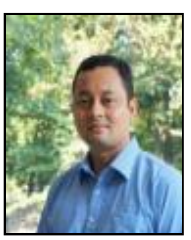

Kurnia Fajar Afgani is the full -time lecturer in Business Risk and Finance group. His research interests are Islamic Finance and Business Economics. His teaching interest includes Business Economics, and Islamic Finance. He graduated with Master of Business Administration from the School of Business and Management (SBM) ITB, and has also obtained a Bachelor of Business Administration from Parahyangan Catholic University (Unpar). He worked for the Bank Syariah Indonesia Company for around 10 years

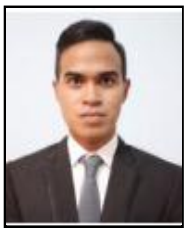

Dematria Pringgabayu is a lecturer from School of Business and Management in Institut Teknologi Bandung in Indonesia, specialized in Human Capital Management and Knowledge Management. He also has practical experience as a Consultant of Internal Quality Assurance in some of Public Universities in Indonesia

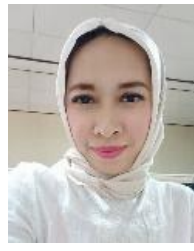

Radia Purbayati is the full-time lecturer in Accounting Department at Politeknik Negeri Bandung. Her major field focused on Banking \& Finance, and Islamic Finance. She has been a lecturer on Banking \& Finance, and Islamic Banking for 10 years. She took her Master Degree at Master of Business Administration from the School of Business and Management (SB) ITB (2007) and Bachelor Degree of Economic Development Studies at Institut Pertanian Bogor (2002). 